\title{
Electron Microscopic Observation of the Sporangial Structure of an Actinomycete, Microellobosporia flavea
}

\author{
By MARTHA RANCOURT AND H. A. LECHEVALIER \\ Institute of Microbiology, Rutgers, The State University, New Brunswick, \\ New Jersey, U.S.A.
}

(Received 20 November 1962)

\begin{abstract}
SUMMARY
Ultrathin sections of sporangia of the actinomycete Microellobosporia flavea were examined with an electron microscope. The sporangial wall is a thin, wrinkled membrane which seems to be an extension of the outer layer of the cell wall of the sporangiophore. A substance, probably a liquid, is located between the sporangial wall and the sporangiospores. The spores are ovoid and consist of a laminated wall in which two layers can be differentiated. The wall is $30-40 \mathrm{~m} \mu$ thick but thickens to $90-120 \mathrm{~m} \mu$ at the point of contact between two spores. Inside the spores one can differentiate a finely granular nucleus, large vacuoles which are probably filled with a fatty substance, and a coarsely granular cytoplasm. The cytology of the sporangiospores of $M$. flavea is similar to that of the conidia of Waksmania rosea.
\end{abstract}

\section{INTRODUCTION}

More than a decade ago the isolation of actinomycetes which formed motile sporangiospores was reported (Couch, 1949). Later Couch proposed to call such organisms by the generic name Actinoplanes (Couch, 1950) and he described, under the name Streptosporangium (Couch, 1955), actinomycetes which formed non-motile sporangiospores. He also suggested that the family Actinoplanaceae be created to group all sporangia-bearing actinomycetes (Couch 1955 a). Strains of both Actinoplanes and Streptosporangium form globose to spherical sporangia containing numerous spores which are randomly distributed at maturity. Recently, organisms which form non-motile sporangiospores arranged in a short single row have been described under the new generic name, Microellobosporia (Cross, Lechevalier \& Lechevalier, 1963). Two species of this new genus of Actinoplanaceae, differing from each other mainly in pigmentation, were described: $M$. cinerea, the type species; and $\boldsymbol{M}$. flavea. Cross and his co-workers showed the presence of the sporangial wall by light microscopy and by electron microscopy, and they followed with light microscopy the formation of the spores within the sporangia. They noted that even though all the spores within a sporangium were of the same age, they were not necessarily of the same size. In the present paper electron microscopy is used to probe the structure of sporangia and sporangiospores of $M$. flavea. Sporangia are borne both on the substrate and on the aerial mycelium, but only the structure of the more accessible aerially-borne sporangia was investigated. These are clubshaped structures borne on the swollen tips of sporangiophores and usually contain from 2 to 5 spores. They range in length from 2 to $9 \mu$ and in diam. from 1.5 to $3 \cdot 6 \mu$. 


\section{METHODS}

Organism. Microellobosporia flavea, No. $\mathbf{3 8 5 8}$ (Culture collection of the Institute of Microbiology of Rutgers).

Gronth and preliminary treatment of the organism. Potato + carrot agar medium (Segretain, Drouhet \& Mariat, 1958) was poured into Petri dishes. The surface of the solid medium was covered with a film of cellophan (Chabbert \& Patte, 1960) and inoculated with a cell suspension which was spread over the surface of the cellophan. The plates were incubated at $28^{\circ}$ until mature sporangia were abundant (about 10 days). The cellophan membranes were removed from the medium and the growth that they carried was scraped off with an inoculating needle. The material thus collected was suspended in acetate-veronal (sodium barbital) buffer (Kellenberger, Ryter \& Séchaud, 1958) and was sedimented by centrifugation.

Fixation. The procedure of Kellenberger et al. (1958) was followed with minor modifications. The fixative was a $1 \%(\mathrm{w} / \mathrm{v})$ solution of osmium tetroxide in acetateveronal buffer ( $\mathrm{pH} \mathrm{5.9)}$ to which traces of calcium chloride were added just before use. The previously sedimented organisms were suspended in this fixative and left there overnight. After proper centrifugation and washing, the fixed organisms were embedded in $2 \%(\mathrm{w} / \mathrm{v})$ agar which was cut in small $\left(1-2 \mathrm{~mm} .^{3}\right)$ blocks. These were suspended in $0.5 \%(\mathrm{w} / \mathrm{v})$ aqueous uranium acetate for $1 \mathrm{hr}$.

Embedding. After fixation, the specimens were dehydrated with ethanol. After having been passed twice through propylene oxide, they were embedded in Epon 812 (Shell Chemical Co., San Francisco) according to the method of Luft (1961) by using 3 volumes of his mixture $A$ for 7 volumes of his mixture $B$.

Thin sectioning. After proper paring, the resin blocks were sectioned either with a Porter-Blum microtome (Ivan Sorwall, Inc., Norwalk, Connecticut, U.S.A.) equipped with glass knives or with an LKB Ultratome microtome (L.K.B. Instruments, Inc., 4800 Rugby Avenue, Washington 14, D.C., U.S.A.) equipped with a diamond knife. The sections were floated on $10 \%(v / v)$ acetone in water and were picked up on collodion coated grids.

Electron microscopy. The sections were examined with an RCA-3D electron microscope (aperture, $25 \mu$ ) operated at $50 \mathrm{Kv}$., and photographed on Eastman Kodak Lantern Slides at an instrumental magnification of 8000.

\section{RESULTS AND DISCUSSION}

Not a single section was obtained which passed through the whole sporangium and sporangiophore. This is not surprising when one considers the large size of this whole structure. At best, some sections were obtained which passed through the apex of a sporangiophore to which two spores were still attached (Pl. 1, fig. 1), or sections were obtained through three spores but not the sporophore (Pl. 1, fig. 2).

The sporangial wall appears as a thin, loosely-wrinkled membrane which looks like an extension of the outer covering of the cell wall of the sporangiophore (Pl. 1, figs. 1 and 3 ). Inside the sporangium, between the spores and the sporangial wall, is located an electron light, reticulated to granular substance. It is difficult to measure accurately the thickness of the sporangial wall, since one is never sure that the wall has not been cut obliquely, but this thickness was estimated at 5-6 $\mathrm{m} \mu$. 
Sectionsof spores, cut perpendicularly to the long axis of the sporangium, are round. Cutting the spores through the long axis of the sporangium revealed an ovoid shape. The walls of the spores are laminated and two main layers of different density can be seen in most sections, the outer layer being the darker one. The spore walls are $30-40 \mathrm{~m} \mu$ at the equator and thicken into pads at the point of contact between two spores. These pads $(90-120 \mathrm{~m} \mu)$ are mainly due to the thickening of the outer layer. The spore walls exhibit another anatomical feature which is always located in the area where the thickening of the interspore pads starts. It is reminiscent of a plasmodesm and might represent a point of cytoplasmic contact between two adjacent immature spores before they are separated by the obesity of maturity, or it might indicate a point of contact, at some stage of maturation, between the cytoplasm of the spores and the sporangial membrane. Such structures can be seen on Pl. 1, figs. 1 and 2; in fig. 1 two arrows point to a pair of such structures located on adjacent spores. In addition, the interspore pads and more strikingly the spore-wall pad which rests on the sporangiophore, exhibit two electron light areas which look like an extension of the inner spore wall layer. On Pl. 1 , figs. 1 and 3 , these areas appear as two oblique lines converging toward the inside of the spore.

Within the spores three main cytological structures can be noted. (1) A large ovoid, more or less centrally located mass of a very finely granular substance; by its very location, one would be tempted to call it a nucleus. Its structure is different from that previously observed in 'nuclei' of spores of Streptomyces which had been fixed, stained and embedded by the same method used here for Microellobosporia flavea. (2) Numerous electron-light vacuoles. (3) A coarsely granular material, darker than the 'nucleus', which fills up whatever space is left, and which is probably the cytoplasm. Since the spores of $M$. flavea were easily stained with Sudan Black it is a fair assumption that the large vacuoles are formed by the deposition of a fatty storage material. An attempt to identify this compound as poly- $\beta$-hydroxybutyric acid failed (Slepecky \& Law, 1960).

Macroscopically, the growth of strains of Microellobosporia resembles that of Streptomyces; microscopically, at least at first glance, it is reminiscent of Waksmania (Lechevalier \& Lechevalier, 1957). It is interesting that sections of spores of $M$. flavea are very similar to sections of spores of $W$. rosea (Pl. 1, fig. 4) and somewhat different from what we would consider a typical section of a spore of a Streptomyces (Pl. 1, fig. 5). By comparing these pictures of organisms which have all been treated in the same manner one will note the greater abundance of vacuoles in Microellobosporia and Waksmania than in Streptomyces, and the rather light unevenlydense nuclear material of the Streptomyces which contrasts with the evenlygranular structures of the other two organisms. Study of additional strains of these and related organisms may permit some generalizations with phylogenic implications. Along this line of thought, we are tempted to compare the sporangial wall in Microellobosporia with the outer layer of the sporogenic hyphae of Streptomyces, which breaks up into spore-sized segments, and which finally enrobes each mature spore (Glauert \& Hopwood, 1961). Microellobosporia could then be considered as short chained Streptomyces in which the outer layer of the sporogenic hyphae does not break up and does not cover each spore. Rather, this outer layer remains continuous around the whole chain of spores, and some fluid is probably 
present between the sporangial wall and the spores. Waksmania may well be a link between Microellobosporia and Streptomyces since its spores are non-sporangial like the Streptomyces, and its cytology is strikingly similar to Microellobosporia.

The authors thank Miss Pauline E. Holbert (Holbert Microscopy Laboratory, Glen Ridge, New Jersey) for her kind and patient cooperation and for the photographs presented in Plate 1 . The valuable suggestions of Dr S. Weinreb were greatly appreciated. This work was supported by Grant G-9694 from the National Science Foundation.

\section{REFERENCES}

Chabbert, Y. A. \& Patte, J. C. (1960). Cellophan transfer. Appl. Microbiol. 8, 193.

Covch, J. N. (1949). A new group of organisms related to actinomyces. J. Elisha Mitchell sci. Soc. 65, 315.

Covch, J. N. (1950). Actinoplanes, a new genus of the actinomycetales. J. Elisha Mitchell sci. Soc. 66, 87.

Couch, J. N. (1955). A new genus and family of the actinomycetales, with a revision of the genus Actinoplanes. J. Elisha Mitchell sci. Soc. 71, 148.

Covcr, J. N. (1955a). Actinosporangiaceae should be actinoplanaceae. J. Elisha Mitchell sci. Soc. 71, 269.

Cross, T., Lechevalier, M. P. \& Lechevalier, H. A. (1963). A new genus of the Actinomycetales: Microellobosporia gen.nov. J. gen. Microbiol. 31, 421.

Glauert, A. M. \& Hopwood, D. A. (1961). The fine structure of Streptomyces violaceoruber (S. coelicolor). III. The walls of the mycelium and spores. J. biophys. biochem. Cytol. 10, 505.

Kellenberger, E., RYter, A. \& Sḱchaud, J. (1958). Electron microscope study of DNA-containing plasms. J. biophys. biochem. Cytol. 4, 671.

Lechevalier, M. P. \& Lechevalier, H. A. (1957). A new genus of the Actinomycetales: Waksmania gen.nov. J. gen. Microbiol. 17, 104.

LUFT, J. H. (1961). Improvements in epoxy resin embedding methods. J. biophys. biochem. Cytol. 9, 409.

Segretain, G., Drouhet, E. \& Mariat, F. (1958). Diagnostic de Laboratoire en Mycologie Médicale. St. Mandé, France: Editions de la Tourelle.

SLEPECKY, R. A. \& LAw, J. H. (1960). A rapid spectrophotometric assay of $\alpha, \beta$-unsaturated acids and $\beta$-hydroxy acids. Analyt. Chem. 32, 1697.

\section{EXPLANATION OF PLATE 1}

Electron microphotographs of thin sections of spores of Actinomycetes.

Fig. 1. Section of sporangiophore and sporangium of Microellobosporia flavea $3858 . \times 22,200$.

Fig. 2. Section of sporangium of $M$. flavea $3858 . \times 20,000$.

Fig. 3. Section of sporangiophore and sporangium of $M$. flavea 3858 . $\times 24,000$.

Fig. 4. Section of spore of Waksmania rosea $3748 . \times 29,600$.

Fig. 5. Section of spores of Streptomyces violaceus $829 . \times 21,000$. 
Journal of General Microbiology, Vol. 31, No. 3

Plate 1

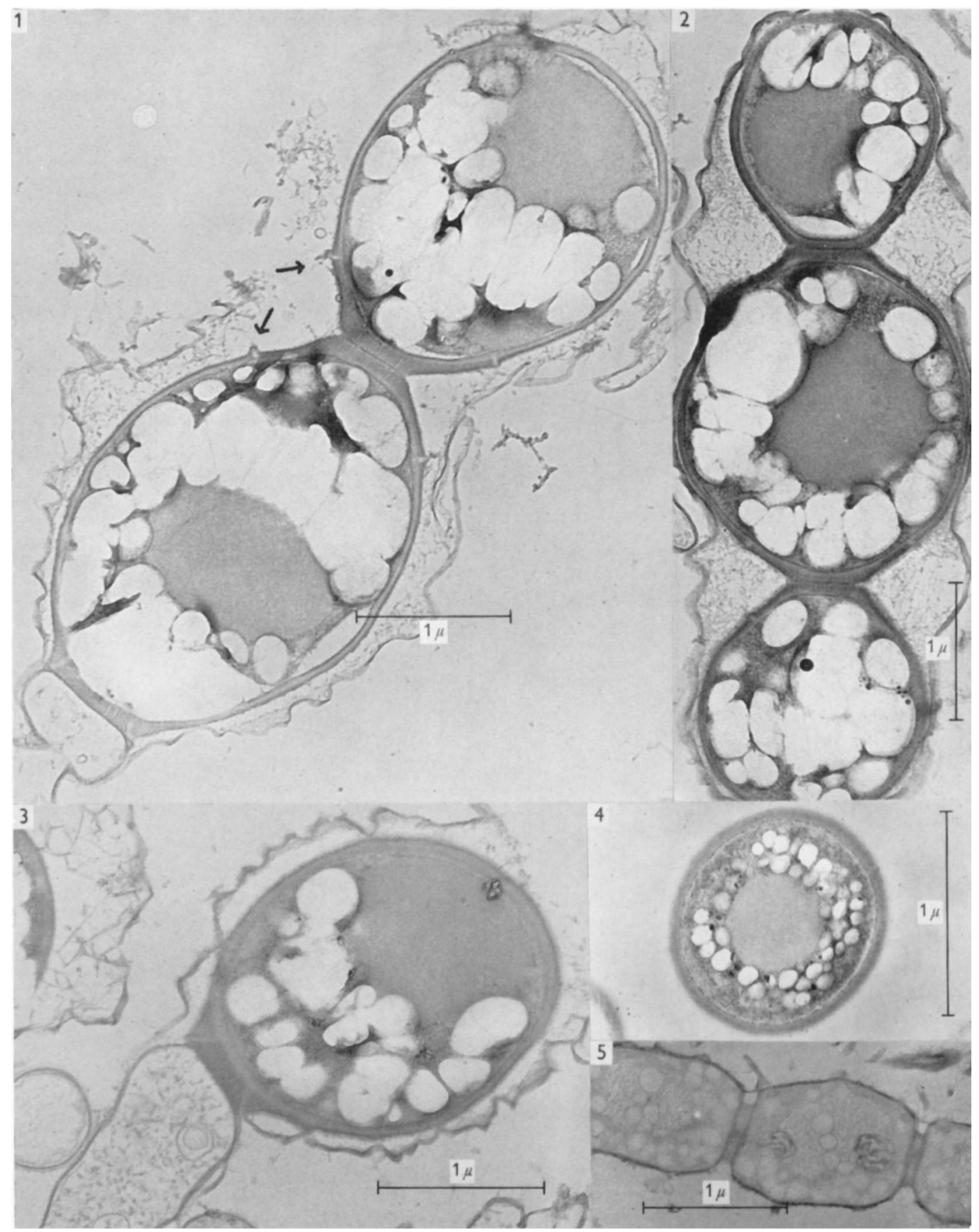

